\title{
Teaching and Practicing the Quadriga in Medieval Norway: A Reading of Barlaams ok Josaphats Saga
}

\begin{abstract}
The present volume establishes that Christian liturgy and religious rituals were the main tools for the transformation of the self after the introduction of Christianity in various cultural contexts of medieval Europe. The liturgical ritual was the ultimate arena and outer manifestation of the cognitive and behavioral changes required by individuals and which were inspired in them by the Church. In this article, I will discuss whether the same tools for transformation were relevant in medieval Norway and how self-reflection and cognitive change were triggered not only during the liturgy but also through other activities, such as the reading of literature. The primary focus will be on the medium of the book, here exemplified by an Old Norse translation of the pan-European legend about Barlaam and Josaphat as preserved in its main manuscript Holm Perg 6 fol., c. 1250. By studying the content of the saga, its narratological structure, and the mise en page of the manuscript, I will argue that the text foregrounded the Christian quadriga model of interpreting and may have served to teach this model to its readers, i.e. members of the upper social class in medieval Norway during the second half of the thirteenth and the beginning of the fourteenth century. This book itself, with its specific mise en page, may thus be seen as a tool assisting in the transformation of the self, in a similar way as the liturgy.
\end{abstract}

\section{Introduction: Liturgy in Medieval Norway}

The Christian religion, with its rituals and rites, was introduced to Norway around the year 1000. ${ }^{1}$ From the 1100 s onwards, many liturgical books were written, and used during liturgical practice in churches all over the country. Unfortunately, few of these are preserved in their entirety as individual leaves of such manuscripts were massively reused as covers for booklets by Danish-Norwegian administrators, accountants and tax officials after the Reformation of $1536 / 37$. Although many of the liturgical books were destroyed in this way, about 6000 fragments still exist from more than one thousand different liturgical books. These fragments testify to the importance of liturgical practices in Norway during the first couple of centuries after the introduction of Christianity. ${ }^{2}$

\footnotetext{
${ }^{1}$ On the process of Christianization, see Sawyer and Sawyer 1997.

${ }^{2}$ For a detailed study of these fragments, see Gjerløw 1968; Gjerløw and Karlsen 2013; Ommundsen 2007.
} 
In addition to the liturgical fragments themselves, there exist in Old Norse (as in many other medieval vernaculars) a genre of texts that explain the liturgy, known as expositions of the Mass, or expositiones missae. ${ }^{3}$ Sometimes the same person wrote both liturgical fragments and expositions of the Mass. For example, one scribe seems to have written four different liturgical fragments in Latin and expositions of the Mass preserved in the Old Norse Homily Book, AM 619 4to (c. 1200). ${ }^{4}$ The scribe seems to have been learned, competent and productive, well versed in Latin and Old Norse language and traditions, as well as in music. He wrote for secular priests and canons, i.e. for people who were not part of the Benedictine monastic community. He himself may have belonged to a scribal community related either to the chapter of Bergen Cathedral, or to the Augustinian Abbey of St John. ${ }^{5}$

One of the homilies in the Old Norse Homily Book, the Stave Church Homily, deserves special attention here, as it is an example of the above-mentioned genre of expositions of Mass. In this homily, the various architectural parts of the church are linked to specific Christian qualities and virtues. ${ }^{6}$ For example, the choir of the church represents the saved souls in Heaven, while the church-ship represents worldly Christendom; the altar is Christ himself; the entrance is the true faith, etc. By such explicit explanation of the allegorical meaning of the building of the church, the members of the congregation were taught to interpret the physical world around them allegorically, and were given an opportunity to practice such 'reading' habits.

The spatial context of the church and the Mass itself were indeed the ideal contexts for the cognitive exercise of connecting Christ's passion and salvation history to one's everyday life. This would have been assisted by bodily and sensory involvement, moving through the physical surroundings, as well as listening to the liturgy and the explanations of the physical surroundings. ${ }^{7}$ Even though these practices are irreversibly lost for us, the material and textual remnants that we still have - such as the churches themselves, the liturgical fragments, and explanations of Mass such as the Homily book - give us an idea of how people were tuned into the Christian paradigm of thought and interpretation. In this article, we will turn to the material remnants of books (by focusing on one specific manuscript, see below) and discuss how the books themselves, i.e. the way they were written and their mise en page, may have assisted the internalization of the new cognitive model promoted by the Church.

\footnotetext{
${ }^{3}$ On the history of the genre, see Hareide 2016, where other manuscripts preserving the genre are discussed. See also Romano's article in this volume on the Ordo Romanus XI, which belongs to a genre that schematically explains what happens before a baptism ritual.

${ }^{4}$ Two of them are discussed by Gjerløw 1968, 35 and another two are discussed by Ommundsen 2010.

${ }^{5}$ Ommundsen 2010, 149-150.

${ }^{6}$ For a discussion on the link between the space of the physical building, the liturgy and the community, based on Santa Maria in Trastevere, see Dale Kinney's article in this volume. She refers to the many architectural metaphors in Scripture and to sermons on the dedication of churches. They would have inspired listeners to think of the physical elements of the church in a metaphorical and allegorical sense, as signifiers of their own inner characteristics. See also Romano's article in the volume dealing with explanations of the Mass and especially with explanations of the liturgical ritual of baptism in seventh-century Rome.

${ }^{7}$ For a discussion of the didactic function of art in Norwegian medieval churches, as parallel to the homilies, see Aavitsland 2010 .

${ }^{7}$ Hareide 2016, 343.
} 


\section{The quadriga model in manuscript culture}

The allegorical reading of the physical space of the church and the liturgy itself, as exemplified by the Stave Church Homily, were based on the quadriga model of reading the Bible, ${ }^{8}$ originally promoted by John Cassian and Augustine and later taken on by Bede, among others. ${ }^{9}$ This was a fourfold model of interpreting Scripture, which combined historical, allegorical, tropological/moral and anagogical senses of the text. In the words of Nicholas of Lyra ( $c$. 1330), the meaning of the different levels is like this: "The letter teaches events, allegory what you should believe, morality teaches what you should do, anagogy what mark you should be aiming for". ${ }^{10}$ In other words, literal/ historical meaning is an actual event or narrative. The allegorical level tells us the symbolic meaning of the event. The tropological/ moral level represents how the historical event may serve as a model for how we should act and behave. The anagogical level gives the deepest, ultimate or eschatological meaning which concerns the ultimate fate of humanity and the afterlife.

Even though "the fourfold sense was the unique privilege of inspired Scripture", ${ }^{11}$ various theologians throughout the Middle Ages merged some of the levels and operated with other models of interpretation instead - sometimes threefold, sometimes even fivefold. The most common trichotomy, which had originated with Origen and Jerome, consisted of historical, tropological and anagogical senses. However, variations existed: Giles of Paris operated with only three senses of the scripture - historical, typical (allegorical) and moral; ${ }^{12}$ Richard of Saint Victor distinguished between historical, allegorical and mystical (or moral) levels; ${ }^{13}$ Peter Comestor writes about a general, a particular and a final understanding, which may be seen as corresponding to allegory, tropology and anagogy. ${ }^{14}$ Thus even though the fourfold sense is considered as "classic and unquestioned", 15 it is most important for us is to note here the possibility for multileveled, but flexible, understanding of Scripture. The variations were based on the merging or overlapping of the "classical" four senses and emphasized "the multivocality of biblical hermeneutics". ${ }^{16}$

Of the four senses, it was the tropological/ moral and the anagogical level that gave greatest scope for the development of the interior man, the cognitive transformation of the self. The primary meaning of the moral level, for example, was not to state what was right or wrong but to provide an arena for reflection upon various dichotomies. The meaning of the moral sense was not to provide a recipe for finding the right way but to inspire reflection upon the process, leading the individual to finding her own 'right' way. This level, and the quadriga as a whole, thus taught people to make connections between the tangible and intangible, the visible and invisible, the here and now and eternal Heaven. This fourfold way of

\footnotetext{
${ }^{8}$ See Hareide 2016, 340.

${ }^{9}$ Lubac 1998, 90.

${ }^{10}$ Cited from de Lubac 1998, 1.

${ }^{11}$ Lubac 1998, 2.

${ }^{12}$ Lubac 1998, 3.

${ }^{13}$ Lubac 1998, 83. His "mystical" level reminds of the one most commonly called "allegorical", while what he calls

"allegorical" overlaps somewhat with the "tropological" sense.

${ }^{14}$ Lubac 1998, 83.

${ }^{15}$ Lubac 1998, 12.

${ }^{16}$ Engh 2014, 30.
} 
thinking was one of the main cognitive transformations introduced or prescribed by Christianity.

The quadriga model of thinking is preserved for us not only through the writings of medieval theologians but also through the very books and graphics of their writings. John Dagenais argues that the various senses of a text are embedded in the very manner in which medieval manuscripts were written:

The heft of a codex, the whispering in the monastic reading room, are past recovery. We cannot know them. But some tracing of medieval readings do remain to provide important clues. The medieval texts that have survived are surrounded in a very physical way by their readings, by the glosses, reclamos, nota benes, allegorizing or moralizing commentaries, pointing hands, accessus, synopses of ancient myths, and so on. ... The text is constantly mediated by glosses, and these glosses, in turn, refer not so much to the text as to the larger and invisible world that is medieval reading itself. ${ }^{17}$

In other words, the fourfold senses, so characteristic of medieval reading, were not only the main topic of medieval theological texts but were also reflected on the mise en page of medieval manuscripts. Medieval manuscripts themselves could work as physical tools for teaching and practicing this model of reading and understanding Scripture, just as the content of the texts and the liturgy did.

The main aim of this article is to discuss whether the quadriga model may have been reflected in Old Norse manuscripts and texts as well. The scope of the article does not allow for a comprehensive study of all Old Norse manuscripts, so a sample text and manuscript need to be chosen. Our attention falls on the Old Norse translation of the Barlaam legend, as preserved in its main manuscript, Holm Perg 6 fol., from the middle of the thirteenth century from Norway. The main reason for choosing this text is its content: the dialogue between the ascetic Barlaam and his pupil Josaphat is at its core a story about the transformation and awakening of the soul, inspired by a myriad of Christian exempla and parables. The saga and the manuscript are also from the same cultural context as the Old Norse Homily Book discussed above - Norway, the first half of the thirteenth century - which allows us to presume that the fourfold model of interpreting text and liturgy were known, at least to the learned members of society. The main question we will discuss here is how the medium of the literary disposition of this text and book may have served to teach the Norwegian secular elite the Christian quadriga model of interpreting their worldly existence as part of universal salvation history. ${ }^{18}$

Before we turn to the empirical evidence, three starting points need to be addressed. First, although I follow Deganais in his argument and will search for the embeddedness of the quadriga model of interpretation on the manuscript pages themselves, with all their graphical peculiarities, this does not mean that the various graphical peculiarities - such as initials, majuscules, punctuations, abbreviations, etc. - did not have other, more practical functions as

\footnotetext{
${ }^{17}$ Dagenais 1994, 26.

${ }^{18}$ See Engh's article in this volume for a comment on how lay people and clerics may have had different needs for mental props and aids when reading (such as illuminated initials, figurative ornamentations, and other graphic features on the manuscript page), compared to Cistercian monks, who were supposed to create their images based on unadorned cloister spaces and sermons inviting to immersive readings. See also Carruthers 2011, 84.
} 
well. These were naturally the most common ways for marking simple linguistic or narratological structuring, such as change of speaker or scene. Such tools were used to make a text easier to comprehend for a reader, to facilitate a certain intended mode of reading or a given message. A linguistic and narratological function of an initial (for example), does not negate, but rather strengthens the potential that lies in the meaning of this initial. If the narratological structure of a text supports a multileveled interpretation of the text, and the graphical program of the text supports the narratological structure, then it is reasonable to argue that the graphical program also points to an intended multileveled interpretation of a text. This is the main line of thought that will be pursued in this investigation, but once again, other potential readings of the text and its mise en page are certainly not excluded.

Second, from a theological perspective, the liturgy is not an arena for the transformation or the awakening of the soul. Rather, it is the arena for the discovery or the rediscovery of what is already inertly embedded in all human souls, the possibility to be one with God. The liturgy is thus not a staging of the meeting with God, it is a meeting with God, involving all the senses and uniting the past, present and future of humanity and the individual, in one moment. ${ }^{19}$ When I write about cognitive transformation and meeting with God, I do not write about the processes that are at the core of the liturgy. Rather, I write about the cognitive transformation that is necessary for the process of accepting and internalizing a new faith. This may be discussed on both macro- and micro-levels: on the macro-level, the Church introduced a set of narratives and rituals which may be seen as tools through which this transformation could happen. On the micro-level, an individual had to be exposed to such tools for cognitive transformation, and through such exposure and teaching, the cognitive transformation could occur within the individual. Repeated exposure to the same tools must have increased the chance for internalization of the main cognitive patterns of thinking, such as the quadriga model, for example. This study will investigate whether and how the quadriga model is embedded in the main manuscript of the Old Norse Barlaam legend. This in turn does not prove that the quadriga model would have been a common way of thinking among the secular elite in thirteenth-century Norway. It will, however, clarify whether people were exposed to a manuscript which contained the potential to inspire quadriga reading and thus cognitive transformation.

A third and final clarification concerns the many terms that may be used concerning a non-literal meaning of a text, such as metaphor, allegory, parable, exemplum, figura, etc. Because of the potential confusion that comes from the overlap and the interrelatedness between these terms, I will aim to use 'allegorical sense' only for the specific (second) level of reading a text; 'non-literal' and 'figurative' meaning, when speaking generically; and 'metaphor' and 'symbolism' in meta- and theoretical discussions. ${ }^{20}$ An exempla and a parable will signify a short story, part of the Barlaam legend.

\footnotetext{
${ }^{19}$ See Engh's introduction.

${ }^{20}$ See Engh and Turner 2019 (forth).
} 


\section{The Nordic Barlaams saga}

The legend of Barlaam and Josaphat was one of the most popular stories in medieval Europe. At its core, this is the story about the Buddha, but when translated into a Christian narrative, it included many references to biblical history. The first Christian version was the Georgian Balavariani, which was translated from Arabic in the ninth or tenth century. Balavariani was translated into Greek and includes many allusions to the works of Johannes Damascenus ( $c$. 675-749) and other known sources. ${ }^{21}$ The Greek version was translated into Latin three times - in 1048, during the $1100 \mathrm{~s}$, and during the $1500 \mathrm{~s}^{22}$ It is the second translation, the one from the $1100 \mathrm{~s}$, called the Vulgata (the common one), that was translated into many of the vernaculars in medieval Europe, including the various Nordic variants. ${ }^{23}$

The Barlaam legend existed in various Nordic versions - a Norwegian one, from $c$. midthirteenth century; two Swedish versions, one based on Legenda aurea from the end of the thirteenth/beginning of the fourteenth century, and another based on the Norwegian version and preserved in the manuscript Holm A 49, or Nådendals klosterbok (Royal Library of Sweden); and one Icelandic version from the end of the fifteenth century, preserved in Holm Perg 3 fol. (1525), or Reykjahólabók (Royal Library of Sweden), based on a Low German Passionael, a translation of the Latin Legenda aurea. ${ }^{24}$

In this article, I will focus on the Old Norwegian version of the Barlaam legend from the middle of the thirteenth century. It was allegedly commissioned by King Hákon Hákonarsson 'the young' (1232-1257), son of Hákon Hákonarsson, as suggested by a note in the Icelandic bishop saga Guðmundar saga Arasonar from the mid-1300s. ${ }^{25}$ The reign of King Hákon is known as a cultural Golden Age in Norwegian history when many Latin and vernacular texts were translated into Old Norse. ${ }^{26}$

The main manuscript of the Norwegian version is Holm Perg 6 fol., dated to $c$. 1250, now in the Royal Library of Sweden. The provenance of the manuscript has been suggested to be either Bergen, Oslo, or Tønsberg, but the language of the saga suggests that it was most probably written in eastern Norway. ${ }^{27}$ At the beginning of the 1400 s, the manuscript was sent to the Vadstena monastery in Sweden, where it was not only read, but possibly also translated to Old Swedish (the younger Old Swedish version). ${ }^{28}$ The Norwegian version was also popular in Iceland and fragments of the text exist in various Icelandic manuscripts. ${ }^{29}$

It is an accepted contention that the Norwegian version of the legend is based on the Latin Vulgata. ${ }^{30}$ The Latin source-texts seems to have been closely followed by the translator: Latin

\footnotetext{
${ }^{21}$ There is much academic discussion about the authorship and the philological history of the Greek version, see Haugen and Johansson 2009, 11-12.

${ }^{22}$ For detailed information on their dating, manuscript witnesses, etc., see Haugen and Johansson 2009, 13-14.

${ }^{23}$ On the transmission and translation of the legend in medieval Europe, see Haugen and Johansson 2009, 15.

${ }^{24}$ See Haugen and Johanssen 2009, 15-28. Here, it is also mentioned that the Swedish version may have been transmitted further to Denmark, but no Danish versions are preserved.

${ }^{25}$ Jón Sigurðsson and Guðbrandur Vigfússon (eds.) 1878, 54.

${ }^{26}$ Haugen and Johanssen 2009, 16-17.

${ }^{27}$ For a detailed review of the discussion and further references, see Rindal (ed.) 1981, 18.

${ }^{28}$ Rindal (ed.) 1981, 22.

${ }^{29}$ See Rindal 2009; Rindal (ed.) 1981; ONP 1989, 32-33. The Icelandic copies of the Norwegian version should not be confused with the Icelandic translation of a German version of the legend, as preserved in Holm Perg 3 fol., c. 1525.

${ }^{30}$ For a discussion of the possibilities of other language source texts, see Haugen and Johansson 2009, 16-18.
} 
grammatical constructions are sometimes even transmitted in the Old Norse language, despite their incorrectness in Old Norse. Although the translator faithfully reproduced his source-text, the Old Norse version also includes a few adaptations and additions to the Latin. ${ }^{31}$ The translator seems therefore to have been a learned theologian with substantial knowledge of both Latin tradition and Norse cultural context. Even though the Old Norse translation is fairly close to its original, I will still regard the text as a product of its Old Norse cultural context as promoted by contemporary translation studies. ${ }^{32}$ Whatever the translator chose to do - to stay faithful to or change the source-text - it was done in order to serve the new target context and to fit the cultural competence and need of the new target audience.

The main story line of Barlaams saga is Josaphat's formative inner process under the close guidance and supervision of his teacher Barlaam while learning about and accepting the Christian God. Within this narrative core with a beginning and an end, the saga contains 24 independent short stories. ${ }^{33}$ Some of these short stories are based on the Latin original, while others are unknown in other versions of the saga and seem to have been included by the Norse translator. Sixteen of these stories (ten non-Christian exempla/stories not based on authoritative Christian texts and six New Testament stories) include explicit explanations, skýring or pýding. These will therefore be of primary significance when we discuss how the Norwegian audience could have learned and practiced the quadriga model. Two of these sixteen stories will be omitted from the analysis, as one of them, namely the parable about the devils (i.e. women) who tempt men has a different structural function in the sagas a whole, compared to the others; and the other, namely the parable of the tame gazelle, is not preserved in the main manuscript Holm Perg 6 fol. The remaining fourteen stories will be analyzed in detail, see Table 1.

The only manuscript that contains all of these fourteen stories is the main manuscript Holm Perg 6 4to (text a in Rindal's edition) and this manuscript will be at the core of the investigation. Five of these stories also appear in AM 232 fol (b in Rindal's edition), an Icelandic manuscript from the beginning of the fifteenth century, and this manuscript will be examined for partial comparison in these five cases. ${ }^{34}$

Holm Perg 6 4to includes only Barlaams saga. There are no chapter headings or rubrics in the manuscript, but paragraphs are introduced by initials. The initials are red on the first 111 folios and then alternate between red and green. ${ }^{35}$

\footnotetext{
${ }^{31}$ For examples, see Haugen 2009.

${ }^{32}$ See for example Toury 1995.

${ }^{33}$ These include ten exempla of oriental origin, six stories from the New Testament, seven stories of legendary or biblical character, and lastly Aristides' apologia. Haugen 2009 calls them interpolations. The terms used for these short stories in Old Norse are dǿmi, dǿmi saga, or just saga, while the Latin terms are parabola, sermo, narratio, or in one case exemplum. Odd Einar Haugen $(2009,48)$ argues that the Old Norse terms are used very consistently: apologias are accounted for as dǿmisaga, stories from the New Testament as saga, and independent short stories added by the Norse translator as dǿmi. See list of all stories in Haugen 2009, 56-57.

${ }^{34}$ For more information about the manuscript, see Rindal (ed.) 1981, 22-25. See also https://handrit.is/en/manuscript/view/da/AM02-232. AM 230 fol. (manuscript $\mathrm{c}$ in Rindal's edition) is another manuscript which could have been included in the analysis, as it also contains many of the parables, see Rindal (ed.) 1981, 51. The manuscript is, however, unfortunately not digitalized and will therefore be left out of the investigation. The other manuscripts that are used in Rindal's edition are too fragmentary to be relevant.

${ }^{35}$ Rindal (ed.) 1980, ix.
} 
A knowledgeable translator/ scribe, working at a professional scribal center, may be presumed to have assimilated the quadriga model of interpretation (of text and ritual). As suggested by Deganais, such internalized thinking patterns may have conditioned the way they wrote, organized and structured their text, narratologically and graphically. ${ }^{36}$ In the following we will have a closer look at how the fourteen stories that have explicit explanations are written down and structured in paragraphs (by the use of initials) on the manuscript pages. The aim of the analysis, as already mentioned, will be to discuss whether the way these stories and their multileveled explanations were written down and structured on the manuscript page may have had the potential to inspire their reader(s) to think along the quadriga model. I will discuss this question by looking closely at the correspondence between:

- $\quad$ the content of the parables and the different levels of explanations;

- the narrator's voice and comments;

- the graphical organization of the parables and their explanations in paragraphs by means of initials.

Correspondence between these elements will be interpreted to indicate that the book itself had the potential to encourage the reader to make a multileveled reading of the passages and thus, to practice his/her quadriga. As already mentioned, this does not exclude other possible and more pragmatic function of the initials. Conclusively, we will discuss how the potential for practicing historical, allegorical, moral and tropological reading may have been relevant for the reader's professional and personal existence.

Table 1 - Page and folio numbers of the fourteen parables analyzed in the article in (respectively) Rindal's edition from 1981, Holm Perg 64 to and AM 232 fol.

\section{Exempla of non-Christian origin}

\begin{tabular}{|c|c|c|c|}
\hline & Rindal (ed.) 1981 & Holm Perg 6 fol. & AM 232 fol. \\
\hline $\begin{array}{l}\text { 1. The parable about the king's brother and the } \\
\text { horn of death }\end{array}$ & 12 & $11 \mathrm{~b}$ & - \\
\hline 2. The parable about the four wooden chests & 13 & $12 \mathrm{~b}$ & - \\
\hline $\begin{array}{l}\text { 3. The parable about the hunter and the nightin- } \\
\text { gale }\end{array}$ & 30 & $32 \mathrm{a}$ & - \\
\hline 4. The man and the unicorn & $47-48$ & $51 \mathrm{a}$ & - \\
\hline $\begin{array}{l}\text { 5. The parable about the man and the three } \\
\text { friends }\end{array}$ & 49 & $53 a$ & - \\
\hline 6. King for one year & $52-53$ & $56 \mathrm{~b}$ & $4-4 v$ \\
\hline 7. The king and the happy couple & 64 & $70 \mathrm{~b}$ & $7 v-8 r$ \\
\hline 8. The parable about the rich son and the poor girl & $67-68$ & $75 a$ & $9 \mathrm{r}-9 \mathrm{v}$ \\
\hline
\end{tabular}

\footnotetext{
${ }^{36}$ The correspondence between the mise en texte and mise en page in Old Norse manuscripts is indicative not only of the scribe's competence and intention, but also of the way the book may have been used, for example privately or publicly read. A high degree of correspondence between textual and graphical features may have eased the public reading of the book, as based on the visual emphasis, the reader would have been able to find a specific passage quickly and would have known when to vocally emphasize important textual passages. A lower level of correspondence may suggest that the book was supposed to be read privately, when the reader would have had the luxury of pacing the reading, depending on his own needs, see Eriksen 2014.
} 
Stories based on the New Testament

\begin{tabular}{|l|l|l|l|}
\hline & Rindal (ed.) 1981 & Holm Perg 6 fol. & AM 232 fol. \\
\hline $\begin{array}{l}\text { 1. The sower, Matthew 8, 3-9; 18-23; Mark 4, 3- } \\
\text { 20; Luke 8, 4-15 }\end{array}$ & 11 & $10 \mathrm{a}$ & - \\
\hline 2. The rich man and Lazarus, Luke 16, 19-31 & 27 & $28 \mathrm{~b}$ & - \\
\hline $\begin{array}{l}\text { 3. The wedding of the king's son, Matthew 22, 2- } \\
\text { 14 }\end{array}$ & 27 & $28 \mathrm{~b}$ & - \\
\hline \begin{tabular}{l} 
4. The ten virgins, Matthew 25, 1-13 \\
\hline 5. The parable of the prodigal son, Luke 15,11-32
\end{tabular} & 28 & $30 \mathrm{a}$ & - \\
\hline $\begin{array}{l}\text { 6. The man who had a hundred sheep and one } \\
\text { was lost, Luke 15, 4-7 }\end{array}$ & 39 & $40 \mathrm{~b}$ & $1 \mathrm{r}$ \\
\hline
\end{tabular}

\section{Worldly concerns and heavenly salvation}

The eight exempla of non-Christian origin have a common narrative pattern. The parable about the unicorn and the parable about the man and the three friends, which follow each other in the manuscript, are representative examples and will be discussed in detail here. I will return to the other parables in the section on 'Patterns of writing and reading' below.

The parable of the unicorn is not begun with an initial. Rather, it is a part of a long speech by Barlaam on various topics. In the middle of a paragraph, the parable is introduced: "Oc pykki mer likazt at iafna peim við mann pann. er firi ræzlo saker. oc otta. flyði vnndan dyri pui hinv ræðelega. er heitir unicornius". ${ }^{37}$ (And to me it seems best to compare them [people] to a man, who was running away from a dreadful animal, that is called a unicorn, because of his fear and anxiety.) The rest of the paragraph contains the parable:

Because of fear and anxiety, a man was running away from a dreadful animal that is called Unicornus. And as he became very distressed and lost all his senses by hearing the animal's sounds and his roar and his threatening laughter, he ran with all his might to save himself, so that the animal would not devour him. And because of the extreme fear, he did not notice in which direction he was running, and by a misfortune he fell down a considerably high and steep abyss. And while he was falling, he grabbed a tree branch, and he held on to it with both hands as hard as he could, and with his feet he managed to step onto a little cleft in the rock. And he thought that he had saved himself. But as he looked up above, he caught sight of two mice, one of them white, the other black. They were lying there, gnawing with great intensity on the roots of the tree that he was holding on to, and it would be just a short while before they had managed to gnaw through the roots. Thereafter he looked down, and there he saw a huge and exceedingly ferocious dragon who blew fire with such a rage and opened his jaws so terrifyingly, that it seemed that he was preparing to devour him if he was to fall down. When he looked at the cleft in the rock on which he had stepped with his feet, he saw four heads of the type of snakes called Aspis, creeping out, looking evil and poisonous. But above all these dangers, he was petrified by anxiety, understandably enough, as he was in such a great danger. Then he looked up a second time and he saw beautiful and exceedingly tempting honey drops dripping from the branches of the little tree onto which he was holding. And as his mind indulged and delighted in this pleasing sight, all the fear and terror that he felt disappeared and he forgot all his worries: about how the animal Unicornis had chased him, about how the

\footnotetext{
${ }^{37}$ Rindal (ed.) 1981, 47; Holm Perg 6 fol., 51a. Rindal's edition follows the paragraph divisions in Holm Perg 6 fol. and folio numbers are marked in the margins.
} 
dragon who was right under him was prepared to devour him, as well as how the mice were gnawing on the tree to which he was holding on, and also how the poisonous snakes were ready to dig into his feet with their venomous teeth. He overlooked and forgot all this fear and anxiety, but he indulged in the little sweetness that he saw dripping from the tree. ${ }^{38}$

The end of the story coincides with the end of the paragraph. If we are to apply the quadriga model, this section of the story may be read as the literal sense: this is what happened. The next paragraph contains just one sentence, spoken in direct speech by Barlaam, and may be seen as an introduction to the allegorical explanation that follows: "Pesser lutir ero. likenddi peirra manna. er lengi stunda eptir heiminum. en nv skal ec segia per. pyðinga pessarra luta". (This is an image of the type of people who have been in this world for a long time. But now I will tell you the rest of the interpretation).

The explanation starts in a new paragraph: "Dyr pat er unicornius heitir. pa iafna ec við ..." ${ }^{40}$ (The animal, called Unicornis, is a simile for ....), and it continues:

death that always follows one and that always aims to end one's days. And the great abyss under the man symbolizes this world which is full of much evil and many pitfalls and dangers, and where all paths surround the man to drag him into death. The tree branch that he holds on to, and which is eagerly gnawed by the white and black mice, symbolizes each man's lifetime, which passes and runs out each night and day, and both contribute to it. And even though it seems long, a man's life runs out quickly. The four snakes that were mentioned stand for the frail and fragile elements that the human body is made of and that cause it to be always frail, impermanent and easily changeable. The ferocious and gruesome dragon is the depth of Hell always wishing to devour and swallow those people who love and long for worldly happiness and amusement more than for heavenly bliss which they do not see. And the little honey drop symbolizes the sweetness and comfort of this world's pleasures, with which the devil tempts and blinds his followers in such a way that they do not see their own path of salvation.

These interpretations, which may be seen as the allegorical level of interpretation, are given in one single paragraph. Since this is a part of a direct speech from Barlaam to Josaphat, it may also be seen as moral guidance about the interplay between the virtuous and vicious energies that influence the worldly existence of human souls.

Jospahat's response to the story comes in the next paragraph, also introduced by a twoline initial: "Uið pessa dœme sagu. varð. Jospahat gœysi glaðr". ${ }^{41}$ (On [hearing] this parable, Josaphat became splendidly happy.) Josaphat is happy and ecstatic about the truth and justice that he has heard in Barlaam's speech. He asks for more knowledge in order to be enlightened to understand the nature of the physical world and the faith of those who are too concerned with it. Josaphat draws out the essence of the parable, which is relevant for his individual existence, his progress through the physical world and his future with God. This may be seen as constituting the anagogical sense of the parable. The correspondence between Josaphat's response and a two-line initial strengthens the hypothesis that this may be seen as a separate level of interpretation.

\footnotetext{
${ }^{38}$ My translation. For the Old Norse text, see Rindal (ed.) 1981, 47-48; Holm Perg 6 fol., 51a-51b.

${ }^{39}$ Rindal (ed.) 1981, 48; Holm Perg 6 fol., 52a.

${ }^{40}$ Rindal (ed.) 1981, 48; Holm Perg 6 fol., 52a.

${ }^{41}$ Rindal (ed.) 1981, 49; Holm Perg 6 fol., 52b.
} 
The saga continues: in the next paragraph Barlaam responds to Josaphat's thirst for knowledge by giving him the beginning of the parable about the man and the three friends. The initial marks the following:

En barllam svaraðe, pui pykkyr mer likazter men peir er ælska heim penna. en glœma oc afvirða. oc firir lita pa. hina myklu von. er eigi er enn peim firir augum. oc er po vrug. i. sinum tima. sem maðr sa var et ate. pria vini. ${ }^{42}$

And Barlaam answered: this reminds me mostly of those men who love this world, but forget and disgrace and abandon the greatest hope, which is not in front of their sight, but is certain when the time comes, just as a man who had three friends.

Once again, the beginning of the story is marked by a narrator's comment and is visually emphasized. The content of the beginning of the new paragraph, i.e. a narrator's comment suggesting a continuation of a dialogue ("En barllam svaraðe"), may suggest an intention for linking this and the previous parable. This parable follows the previous one narratologically, and a reader would not automatically have discerned it as the beginning of a new parable, unless he knew the saga and the manuscript very well. This paragraph gives us the background information about the main protagonist of the parable: a man who is loyal to two of his friends, but not a very good friend to a third one. This may be seen as the literal/historical sense of the parable.

The next two-line initial introduces a moment of narratological significance: "Sua bar at einn-huernn dagh..." ${ }^{43}$ (This happened one day). One day the man finds himself in trouble and needs to turn to his friends for help. The first two friends reject him, excusing themselves in various ways, while the third friend, surprisingly, offers his help. The man is touched by his unexpected generosity and kindness, from which he seems to learn a lesson about the hidden meaning of things, and about the difference between appearance and actual content, which is given in a separate paragraph. The graphical structure of the story suggests that the literal level (a man has three friends but is loyal and kind to just two of them) is separate from the lesson the man learns from this event (that the physical world has hidden meanings).

A narrator's comment, including Josaphat wondering about the meaning of the saga, is given thereafter in one short paragraph: "Josaphat vndraðe miok pessa sagu. oc bað hann birtta firir ser. priðiung ${ }^{44}$ pessarrar dœme sagu". ${ }^{45}$ (Josaphat wondered much upon this saga and asked him to explain him the meaning of this saga).

The allegorical sense of the story, where Barlaam explains what the three friends symbolize is given in the next paragraph, marked by an initial. The sentence starts with a narrator's comment: "pa svaraðe barlaam. hinn fyrsti vinr. ..."46 (Then Barlaam answered: the first friend ...). The first friend symbolizes money and wealth, and one can take little, if any, of these to the next life; the second friend symbolizes social and enjoyable relationships, which are also only partly relevant for one's existence in the next life; while the third friend is faith

\footnotetext{
${ }^{42}$ Rindal (ed.) 1981, 49; Holm Perg 6 fol., 53a.

${ }^{43}$ Rindal (ed.) 1981, 49; Holm Perg 6 fol., 53a.

${ }^{44}$ The other manuscripts have byðing, see Rindal (ed.) 1981, 51, n. 532.

${ }^{45}$ Rindal (ed.) 1981, 51; Holm Perg 6 fol., 55b.

${ }^{46}$ Rindal (ed.) 1981, 51; Holm Perg 6 fol., 55b.
} 
in God, which is of crucial significance for the afterlife. If one has attended to it, even if not well enough, one will be rewarded generously after one's death. The description of the allegorical sense seems to coincide with a moral lesson to Josaphat, about how one can easily waste his goodness and potential by taking wrong choices, but also that one can be saved if one takes the necessary minimum care of his faith and spirituality. The moral lesson learned by the man in the story is now passed on to Josaphat.

As expected, the fourth anagogical level is also marked by an initial in the next paragraph: "Blezaðr se pu sagðe Josaphat til Barlaams". ${ }^{47}$ (Be blessed, said Josaphat to Barlaam.) This is a narrator's comment which introduces Josaphat's verbalization of his own understanding of the parable, his exclamation of happiness about what he has learned about the world of God and man, and his desire for more knowledge about it all.

To recapitulate: There seems to be a close correspondence between the content, the narratological, and the graphic aspects of the two stories, which follow each other in the saga and are linked through the dialogue. Narratological elements such as the switch from narration to direct speech often mark the beginning of the various levels of interpretation, which are visually marked by two-line initials in the manuscript. This correspondence is, however, not completely rigid, as two of the senses (allegorical and moral) are not distinguished graphically and are given in the same paragraph. This suggests that the scribe of the text may have had a threefold model of interpretation in mind, and not the standard fourfold quadriga model. As mentioned, this was not unusual throughout the medieval period, with various theologians, such as Giles of Paris and Bernard of Clairvaux, operating with a threefold model. The main principles of the quadriga model, and even all the four senses, are easily distinguishable in these parables in Barlaams saga, through the consistent links between their content, narratological structure and graphical disposition.

\section{Mistakes, regrets and forgiveness}

Similar graphical disposition, with variations, is found in the six stories from the New testament (see Table 1 above). These are much shorter than the non-Biblical parables and they are sometimes presented one after the other in order to make a point clearer. The different quadriga levels of interpretations seem nonetheless to correspond both to narratological shifts and to graphical features on the manuscript page. Parables 2, 3 and 4 (see Table 1) will be presented in detail, while the rest will be commented on in the section below.

The story about the rich man and Lazarus, known from Luke 16, 19-31, serves as a starting point of a representative example. ${ }^{48}$ A two-line initial marks the beginning of the story which is part of a grander narrative about God, given by Barlaam to Josaphat in the previous paragraphs: "Aðra sagu segir hann oc til peirra. er fong hava œren. oc vilia po fam af geva. tekr dœme af einum riku manne ..." enough but want to give away little. They can learn from a rich man ...). The story continues: A rich man lived in all comfort and wealth, while Lazarus who was ill and in great need, lived outside the rich man's house. The rich man never helped Lazarus. When the two men

\footnotetext{
${ }^{47}$ Rindal (ed.) 1981, 52; Holm Perg 6 fol., $56 \mathrm{~b}$.

${ }^{48}$ Rindal (ed.) 1981, 27; Holm Perg 6 fol., 28 b.

${ }^{49}$ Rindal (ed.) 1981, 27; Holm Perg 6 fol., 28 b.
} 
died, Lazarus was carried off by God's angels to Heaven, while the rich man was dragged to Hell. While the former had carried his poverty with fortitude, the latter had luck and happiness, which he did not make good use of. This may be seen as the historical sense of the story. The other senses are not given at this stage, as the parable is followed, in the same paragraph, by the next parable about the wedding of the king's son, known from Matthew 22, 214: "Einni sagu iafnar vaR herra iesus kristr himiriki. við iarðeskan" 50 (In one/another story, our Lord Jesus Christ is compared to a worldly king). The transition between the two stories is not visually marked, which suggests that they were to be read as related. This king arranges a rich wedding for his son, and he explains to him that he does not do this because one needs lots of food and drink and entertainment in Heaven, but because unreasonable people do not understand wise things unless these are explained through images and pictures - the wedding is intended to function as a metaphorical lesson. Many of those invited did not come, excusing themselves by important responsibilities and duties at home and in their families.

The next paragraph tells us that when the king saw that, he invited other people and this time his hall was full of guests. While walking around, greeting his guests, the king saw a man who was dressed inappropriately. When asked why he was dressed thus, the man did not answer, and was then taken away and put in the dungeon. Barlaam's interpretation of the episode, which is given in the same paragraph, is that the people who were first invited but did not want to come are symbols of those who have heard the true faith preached to them, but who do not want to accept it. The one with inappropriate clothing symbolizes the Christians who have accepted the faith, but still live inappropriately. Because of that they will be dragged out of the path towards eternal glory and thrown into a place of eternal pain.

The literal sense of the two stories is thus provided in the former paragraph, while the latter paragraph may be characterized as including both the conclusion of the literal sense (the king learning his lesson) and the allegorical sense of the story, giving the symbolic meaning of the different groups of guests. On a similar level as the parable about the man with three friends above, the moral lesson learned by the character in the story may also be read as a moral lesson aimed at Josaphat. The historical, allegorical and moral senses are thus subtly combined, although the anagogical sense is missing at this stage.

The next parable, the one about the ten virgins, is taken from Matthew 25, 1-13. ${ }^{51}$ It is introduced in the following paragraph: "En iafnar vaR herra i einni sagu. við himinriki til likennda. tiv mœyar". ${ }^{2}$ (And in another story, our heavenly Lord is compared to ten virgins.) Five of the them are given oil for good deeds, while the other five are left with empty jars. The allegorical meaning of this is that the first five could follow their Lord to eternal glory, while the last five were rejected as their Lord did not recognize them, as they had not lived according to their faith. This short exemplum is written in one paragraph and may be said to include the literal sense of the story and the allegorical meaning of our worldly existence for our chances for heavenly salvation.

These three parables are told in succession and they form a consistent entity, all dealing with the fate of those who follow and do not follow their faith in their worldly existence. The three New Testament exempla are followed by more stories by Barlaam, written in several

\footnotetext{
${ }^{50}$ Rindal (ed.) 1981, 27, 11. 21-22; Holm Perg 6 fol., 29a.

${ }^{51}$ Rindal (ed.) 1981, 28; Holm Perg 6 fol., 30a.

${ }^{52}$ Rindal (ed.) 1981, 28, Holm Perg 6 fol., 30a.
} 
paragraphs, about what the prophets Isaiah and David, among others, say about Judgement Day: "guð varr man koma openberllega Oc eigi miok pegiannde. elldr man koma brennande. $\mathrm{i}$ hans augliti. en vm huervis hann æðe straumar". 53 (Our God will come clearly and not in silence. Fire will come burning in his face and around him powerful storms). The whole sequence of Biblical stories and its last paragraph are summarized and given a conclusion: "Marga luti slika. oc pui vm lika. mæler David. oc adrer prophetar vm doma dag Oc sva hueria ambun huarer hava illir eða goðer". 54 (Many such things, and other similar ones, says David and other prophets about Judgement Day, and what the good and the bad will get in return).

The following paragraph notes the end of Barlaam's speech: "En er Barlaam hafoe loket rœðo sinni..."55 (And when Barlaam ended his speech...). It recounts that when Josaphat hears these examplas and learns about Judgement Day, he says with tears in his eyes that he truly understands this lesson about the connection between existence in this world and the Heavenly one. As expected, he asks Barlaam for advice on how to live to avoid such a tragic end.

Thematically and narratologically, these three parables have an introduction and a conclusion in common and may be read in the usual three/four-levelled manner: the actual event; the implications of the event in the mini-story itself; Barlaam's moral lesson to Josaphat; and Josaphat's own reflection and conclusion about the story's relevance for his own and humanity's worldly and heavenly existence. This thematic and narrative structure is reflected in the visual structure of the text to a certain extent - the literal levels of the first two parables are given in the same paragraph, while their allegorical and moral explanations are given in one separate paragraph. After the third exemplum, given in a separate paragraph, the text presents its readers with several paragraphs on Judgement day, which may be seen as a discussion of the moral implications of all three exempla. Finally, Josaphat's anagogical reading appears in a separate paragraph.

\section{Patterns of writing and thinking}

The pattern of correspondence between the content, the narratological, and the graphical aspects of the parables is also confirmed in the rest of the short stories that include explanations. Sometimes a couple of parables are related to each other in a similar way as the examples above. This is the case with the parable about the king's brother and the horn of death and the parable about the four wooden chests. The parable about the prodigal son and that about the man who had a hundred sheep and lost one are also linked. ${ }^{56}$ Sometimes a New Testament parable is followed closely by a non-biblical parable, as is the case with the parable about the seed and the one about the king's brother and the horn of death.

The structure of the remaining parables is similar to the one retold in detail above: a threeor four-leveled structure, reminiscent of the quadriga model of interpreting the world. The different levels are not explicitly characterized as quadriga levels, but the repetitiveness of

\footnotetext{
${ }^{53}$ Rindal (ed.) 1981, 29; Holm Perg 6 fol., 31a.

${ }^{54}$ Rindal (ed.) 1981, 29; Holm Perg 6 fol., 31 b.

${ }^{55}$ Rindal (ed.) 1981, 29; Holm Perg 6 fol., 31 b.

${ }^{56}$ See Rindal (ed.) 1981, 38-40. The paragraph structure by means of initial is the same in Holm Perg 6 fol., $40 \mathrm{~b}-41 \mathrm{~b}$ and AM 232 fol., 1r-1v.
} 
this three- or fourfold structure, and the link between the various levels, the narratological structure and the graphic organization in paragraphs certainly makes it possible to argue that this may have been a conscious choice when writing the saga. The text and manuscript seem to reflect the scribe's intention to pass on the quadriga model to the reader and to provide occasions for practicing the interpreting-model. On the literal level, we hear the basic storyline: how a king meets some beggars and kneels in front of them, ${ }^{57}$ or how a king going on a walk in his kingdom observes the everyday life of his people ${ }^{58}$ or how citizens depose their king after a year of glorious kingship, ${ }^{59}$ or how a rich man's son meets a poor man's daughter, is charmed by her wise words and wishes to marry her. ${ }^{60}$ This basic story is then explained, on an allegorical level: the beggars turn out to be God's messengers; the visible world turns out to be insignificant compared to the happiness the king sees through a little hidden hole; the year of glorious kingship turns out to lead to an eternity of misery and pain. Based on this allegorical sense, Barlaam then turns towards Josaphat with a moral discussion of what the story can teach him and how it can guide him in his own behavior and existence. Sometimes the moral lesson to Josaphat reflects the moral lesson learned by the character of the story itself. Finally, sometimes after a new story or two, Barlaam presents the anagogical sense of the story which may concern how to remember God's omnipresence; what true happiness is; or how to prepare for eternity. Josaphat then draws the main conclusion from the story for himself, a conclusion that directly relates to his own choices in his earthly life - to learn more from Barlaam, to spend his life with him, to convince his father to adopt Christianity, to be true to God - in order to secure his own access to Heaven after his death. The repetition of this pattern of structuring the content of the parables is so consistent that once the reader discovers it, the pattern becomes the automatic prism for reading the separate parables and the saga as a whole. The ultimate lesson is that what one experiences with one's physical body through the senses (sight, ${ }^{61}$ hearing, taste, smell, touch) and all aspects of the physical worldly space and time - all this is just a small part of what God's world as a whole has to offer. Depending on how it is perceived and how it is treated, physical existence may be a basis for either eternal bliss in God's kingdom or endless misery in Hell.

The content of the parables and the four levels of interpretation are accentuated by the narratological structure of the saga. The four levels are interspersed with narrator's comments, such as: "Josaphat vndraðe miok pessa sagu. oc bað hann birtta firir ser. priðiung pessarrar dœme sagu". ${ }^{62}$ (Josaphat wondered much about this saga and asked him [Barlaam] to explain its meaning to him.) A shift from one speaker to another also often signals a transition to the next level. There are of course exceptions to the rule, as when Josaphat replaces Barlaam as the speaker without this leading to a transition to the next level of interpretation, but rather to the introduction of a new parable.

\footnotetext{
${ }^{57}$ This corresponds to the parable about the king's brother and the horn of death, Rindal (ed.) 1981, 12.

${ }^{58}$ This is the parable about the king and the happy couple, Rindal (ed.) 1981, 64. The paragraph structure provided by the initials is the same in Holm Perg 6 fol., 70b and AM 232 fol., 8r-8v.

${ }^{59}$ This is the parable about the king for one year, Rindal (ed.) 1981, 52. The paragraph structure provided by the initials is the same in Holm Perg 6 fol., $56 \mathrm{~b}$ and AM 232 fol., $4 \mathrm{r}-4 \mathrm{v}$.

${ }^{60}$ This is the parable about the rich son and the poor daughter, Rindal (ed.) 1981, 67-68. The paragraph structure provided by the initials is the same in Holm Perg 6 fol., 75a-75b and AM 232 fol., 9r-9v.

${ }^{61}$ See Rollo-Koster's discussion on the significance of visualizing and seeing the liturgy, for example the Eucharist.

${ }^{62}$ Rindal (ed.) 1981, 51.
} 
This correspondence between content and narratological structure is strengthened even more by the visual emphasis of the two-line initials. There are exceptions to this rule too, as one level of interpretation may consist of several paragraphs, especially Barlaam's moral reflections which sometimes include many biblical stories and examples. At other times, two levels, especially the literal and the allegorical, may be given in one paragraph, such as in the parable about the hunter and the nightingale. In shorter parables, as the New Testament ones, sometimes even three levels are gathered into the same paragraph (the sower parable, for example). Nonetheless, most initials in the saga appear in connection to the narrator's comments or change of speaker and correspond to a different level of interpretation. The consistency in this correspondence suggests that the multiple levels of interpretations of the parables would have been easy to comprehend not only by the content of the parables, but also by the way the parables were actually written down.

Thus, the next question is: how would such a correspondence between mise en texte and mise en page have influenced the reading of this text? As the initials do not always introduce the beginning of each parable, they would not have been useful in finding a specific story. Most often, the initials mark the various levels of interpretation, which would have made the distinction between these various levels very clear for the reader. Once again, the fact that the initials also mark narratological structure as changes in voice or scene, does not negate, but rather strengthens the emphasis that one level of interpretation is separate from the other. This consistent and repetitive pattern suggests that reading the book as a whole would have presented the reader with an excellent opportunity to practice the quadriga model of thinking and interpreting.

Comparison between the mise en page of some of the parables in Holm Perg 6 4to and the same parables, as preserved in AM 232 fol. shows that the same close correspondence between content/various levels of interpretation, narratological structure/narrator's comments, and paragraph structure provided by initials is also present in the latter manuscript. The paragraph structures of the compared sections are the same in the two manuscripts. The two manuscripts were written and read in two different socio-cultural contexts, but the same tools for structuring the content and form of the text, foregrounding the quadriga model of interpretation, were clearly applicable and relevant in both contexts. This is not at all surprising since the quadriga model was indeed one of the main cognitive tools of Christian thought across spatial and temporal borders.

\section{The owner and the cultural context}

Who, at the end of the thirteenth century in Norway, would have benefitted from such consistent guidance in the quadriga pattern of thinking and interpreting? Around 1300 the manuscript was possibly owned by a certain "Stigr from Liavik". A note on fol. 197, which is now illegible, has previously been deciphered to read "Stigr de Liavik me possidet. qui me furatur ad tartara crine trahatur". (Stigr from Liavik owns me; he who steals me will be dragged to hell by his hair). ${ }^{63}$ The note is in Latin and is written from the perspective of the book itself, which was also common in epigraphic tradition. Agency is projected to the book itself, which communicates in Latin, even though the text it contains is in Old Norse. The potential thief

\footnotetext{
${ }^{63}$ Rindal (ed.) 1980, x.
} 
would have needed to understand Latin in order not to end up in hell, which suggests a learned and Latinate context of user(s).

Stígr was not a very common name in Norway - in the Diplomatarum Norvegicum, we have five men with this name in the period 1200-1400. ${ }^{64}$ In addition, two Latin letters from 1327 name a certain Stigotus Helgason, who seems to have been a participant in a couple of peace treaties between the Norwegian king Magnus and the Danish king Valdemar, and between Duke Knut Porse and some chieftains. Four of the men named Stígr are not very well documented, but it may be possible to identify the fifth, Stígr Hákonarson: probably the king's man in the town of Skien, the son of Hákon Pórisson, who had the same political position before his son. Hákon was related to the Norwegian royal family, through marriage to the sister of Erlingr Viðkunnsson (1293-1355). Erlingr gave land to the Maria Church in Tønsberg to help Stigr's soul. Erlingr received the position of High Justiciar (drottsete) of the country. Magnus IV of Sweden was elected King of Norway as a three-year-old in 1319. During the last part of the Regency, from 1323 until Magnus turned fifteen in 1331, Erlingr led the Norwegian State Board of Royal Authority. ${ }^{65}$

Even if this was not the Stígr who owned the Barlaams saga-manuscript, it might be assumed that at the beginning of the fourteenth century, the manuscript was owned by a learned person who belonged to the top socio-political circles in the east of Norway. We know that this period was characterized by extensive literary activity and manuscript production. ${ }^{66}$ Among the significant literary achievements of the time are the many translations commissioned by King Hákon Hákonarsson, by his son Hákon Hákonarsson the young (responsible for the commissioning of Barlaams saga itself), ${ }^{67}$ and by Queen Euphemia. ${ }^{68}$ In addition, we know of a few major manuscripts written and owned by members of the highest court aristocracy, such as AM 243 b.a. fol. (The King's Mirror), ${ }^{69}$ De la Gardie 4-7 fol (Strengleikar, Elíss saga and other texts), ${ }^{70}$ and Holm Perg 4 (Piðreks saga). ${ }^{71}$ Hauksbók may also be mentioned in this context, as it was owned (and partially written) by Haukr Erlendsson, a professional who worked both in Norway and Iceland. ${ }^{72}$ Some of these texts and manuscripts have earlier been characterized as a speculum for their owners. Linking Christian universal history to the history and cultural context of Scandinavia, the texts and manuscripts may have served their owners not only in their professional functions (often within the administrative, judicial or political sphere) but also on a personal level, to guide them on the true path towards God through self-reflection and religious practice. Similarly, we can imagine that Stígr from Liavik, whoever he was, and other readers of the manuscript, may have had the possibility to learn and practice the art of allegorical, moral and anagogical interpretation by reading Barlaams saga, given the consistency with which this model is represented both in the content of

\footnotetext{
${ }^{64}$ See Rindal (ed.) 1980, x-xi; Rindal (ed.) 1981, *19-*22.

${ }^{65}$ More information about the role of Erlingr Viðkunnsson and the political situation during the first half of the fourteenth century is given in Rindal (ed.) 1980, $\mathrm{x}$.

${ }^{66}$ On the literary environment for the manuscript, see Rindal 2009; Johansson 2015.

${ }^{67}$ See Eriksen 2017.

${ }^{68}$ Ferm et al. 2015; Bandlien 2012.

${ }^{69}$ Seip and Holm-Olsen (eds.) 1947.

${ }^{70}$ Tveitane 1972.

${ }^{71}$ Bertelsen (ed.) 1905-1911.

${ }^{72}$ Eirikur Jonsson and Finnur Jónsson (eds.) 1892-1896; Johansson 2017.
} 
the saga's parables as well as on the very manuscript pages. The repetitive pattern of recounting the parables and of writing them down on the manuscript pages turns the book itself into a compelling and guiding mirror for the spiritual awakening of all its readers.

\section{Conclusion: Participating in Mass and Reading Literature}

In this article, I have argued that based on the correspondence between the mise en texte and the mise en page of Holm Perg 6 fol., texts like Barlaams saga in manuscripts like Holm Perg 6 4to may have functioned as guidance for the practice of the quadriga model of thinking. The content of the saga as well as its graphic presentation on the manuscript pages would have accentuated the differences between the various levels of interpretations. This cognitive ability and habit would have also been useful when engaging with and participating in the Holy Mass. Then all the senses were mobilized in order to connect the individual's human existence and environment with universal salvation history, as clearly explained in homilies such as the Stave Church Homily.

The hypothesis that the parables in Barlaams saga may have had a pedagogical function is strengthened by the visual representations of some of the parables in liturgical contexts. The unicorn-parable is, for example, depicted, in two such contexts. ${ }^{73}$ One is the Amiens psalterium, where the meaning of the image is accentuated by the fact that it is placed immediately next to a picture of Christ hanging on a tree with green leaves. In this context, the two images were probably meant to complement each other and to provoke meditation upon the two opposites: the Tree of Life (which is traditionally seen as the cross on which Christ was crucified) and its antithesis, the Tree of Knowledge (from which Adam and Eve ate). The two images are also relevant for the liturgical texts that surround the images in the manuscript, namely penitential psalms and the Office of the Dead (Officium Defunctorum). ${ }^{74}$ Another visual representation of the parable is found in the church of Vester Broby in Denmark - a fresco from $c$. 1400. In this representation, however, the man is not tempted by honey drops but is eating an apple, an adaptation of the motif which would have made it more recognizable for an audience familiar with the story of the Fall. ${ }^{75}$ The clarity of the didactic image suggests that it may easily have been used actively in the Mass, or it may only have served as meditative inspiration for the congregation.

These two examples clearly show the relevance of the unicorn-exemplum in liturgical contexts. For aristocrats at the end of the thirteenth and the beginning of the fourteenth century in Norway, this and other parables, as written in Holm Perg 6 fol., may have served as a basis for relating one's worldly existence to universal salvation history, not only during Mass, but also during everyday life and activities, such as the reading of books.

Stefka G. Eriksen

Norwegian Institute for Cultural Heritage Research

Stefka.eriksen@niku.no

\footnotetext{
${ }^{73}$ See Aavitsland 2009.

${ }^{74}$ These refer to Luke 17, 33: Whoever seeks to preserve his life will lose it, but whoever loses his life will keep it. See Aavitsland 2009, 143.

${ }^{75}$ Aavitsland 2009, 132.
} 


\section{BIBLIOGRAPHY}

Icelandic names are listed by first names.

Aavitsland K. 2009: "Fra tekst til bilde. Ikonografisk transformasjon av enhjørning-fabelen fra Barlaamlegenden i nordeuropeisk middelalder", in K.G. Johansson and M. Arvidsson (eds.), Barlaam $i$ nord. Legenden om Barlaam och Josaphat $i$ den nordiska medeltidslitteraturen (Bibliotheca Nordica 1), Oslo, 131-152.

Aavitsland K. 2010: "Visualisert didaktikk? Det talte og det malte ord i norsk middelalder", in O.E. Haugen and Å. Ommundsen (eds.), Vår eldste bok. Skrift, miljф og biletbruk $i$ den norske homilieboka (Bibliotheca Nordica 3), Oslo, 217-246.Bandlien B. (ed.) 2012: Eufemia - Oslos Midde-lalderdronning, Oslo.

Bertelsen H. (ed.) 1905-1911: Piðreks saga af Bern, København.

Carruthers M. 2011: The Craft of Thought: Meditation, Rhetoric, and the Making of Images, 400-1200, Cambridge.

Dagenais J. 1994: The Ethics of Reading in Manuscript Culture. Glossing the Libro de buen amor, Princeton.

Eirikur Jonsson and Finnur Jónsson (eds.) 1892-1896: Hauksbok: udgiven efter de Arnamagnaeanske Handskrifter No. 371, 544 og 675, (quarter) samt forskellige Papirshandskrifter af det Kongelige Nordiske Oldskrift-Shelskab, Copenhagen.

Engh L.C. 2014: Gendered Identities in Bernard of Clairvaux's Sermons on the Song of Songs. Performing the Bride (Europa Sacra 15), Turnhout.

Engh L.C. and Turner M. 2019 (forth.): "Introduction: A Case Study of Symbolic Cognition", in L.C. Engh (ed.), Marriage Symbolism, Turnhout.

Eriksen S.G. 2014: Writing and Reading in Medieval Manuscript Culture (Medieval Texts and Cultures of Northern Europe 25), Turnhout.

Eriksen S.G. 2017: "Romance. An Examination of the Links between European Romance and Old Norse Saga Writing", in S. Jakobsson and Á. Jakobsson (eds.), The Routledge Research Companion to the Medieval Saga, London and New York, 59-73.

Ferm O., Hedström I., Loden S., Pettersson J. and A. (eds.) 2015: The Eufemiavisor and Courtly Culture: Time, Texts and Cultural Transfer, Stockholm.

Gjerløw L. (ed.) 1968: Ordo Nidarosiensis Ecclesiae. Libri liturgici provinciae Nidrosiensis medii aevi 2, Oslo.
Gjerløw L. and Karlsen E. 2013: Latin Manuscripts of Medieval Norway: Studies in Memory of Lilli Gjerl $\phi w$ (Nota bene 5), Oslo.

Hareide S. 2016: "Messuskýringar: Old Norse Expositions of the Latin Mass", in S.G. Eriksen (ed.), Intellectual Culture in Medieval Scandinavia, c. 11001350 (Disputatio 28), Turnhout, 337-372.

Haugen O.E. 2009: "Forteljingane i forteljinga", in K.G. Johansson and M. Arvidsson (eds.), Barlaam in nord. Legenden om Barlaam och Josaphat $i$ den nordiska medeltidslitteraturen (Bibliotheca Nordica 1), Oslo, 47-74.

Haugen O.E. and Johansson K.G. 2009: "De nordiske versjonene av Barlaam-legenden", in K.G. Johansson and M. Arvidsson (eds.), Barlaam in nord. Legenden om Barlaam och Josaphat $i$ den nordiska medeltidslitteraturen (Bibliotheca Nordica 1), Oslo, 11-31.

Haugen O.E. and Ommundsen Å. 2010: "Nye blikk på homilieboka", in O. E. Haugen and Å. Ommundsen (eds.), Vår eldste bok. Skrift, miljø og biletbruk $i$ den norske homilieboka, Oslo, 9-34.

Johansson K.G. 2015: "Queen Eufemia, Norwegian Elite and the Background of the Eufemiavisor", in O. Ferm, I. Hedström, S. Loden, J. Pettersson and M. Åkestam (eds.), The Eufemiavisor and Courtly Culture: Time, Texts and Cultural Transfer, Stockholm, 136-161.

Johansson K.G. 2017: “The Hauksbók: An Example of Medieval Modes of Collecting and Compilation", in K. Pratt, B. Besamusca, M. Meyer and A. Putter (eds.), The Dynamics of the Medieval Manuscript. Text Collections from a European Perspective, Göttingen, 131-145.

de Lubac H. 1998: Medieval Exegesis. Vol. 1. The Four Senses of the Scripture, trans. by M. Sebanc, Edinburgh.

Ommundsen Å. 2007: Books, Scribes and Sequences in Medieval Norway, 2 vols. PhD dissertation at University of Bergen.

Ommundsen Å. 2010: "Homilieboka og dei liturgiske fragmenta", in O.E. Haugen and Å. Ommundsen (eds.), Vår eldste bok. Skrift, miljø og biletbruk i den norske homilieboka (Bibliotheca Nordica 3), Oslo, 131-150. 
ONP = Den Arnamagnæanske Kommision (ed.) 1989: Ordbog over det norrøne prosasprog. Registre, København.

Rindal M. (ed.) 1980: Barlaams ok Josaphats Saga. Manuscript No 6 fol, in the Royal Library Stockholm and the Norwegian Fragments, Oslo.

Rindal M. (ed.) 1981: Barlaams ok Josaphats Saga, Oslo.

Rindal M. 2009: "Barlaams ok Josaphats saga i det norske litterære miljøet", in K.G. Johansson and M. Arvidsson (eds.), Barlaam $i$ nord. Legenden om Barlaam och Josaphat $i$ den nordiska medeltidslitteraturen (Bibliotheca Nordica 1), Oslo, 31-46.

Sawyer B. and Sawyer P. 1997: Medieval Scandinavia: From Conversion to Reformation, ca. 800-1500, Minneapolis, London.
Seip D.A. and Holm-Olsen L. (eds.) 1947: Konungs Skuggsjá: Speculum regale. De norske håndskrifter $i$ facsimile, Oslo.

Sigurðsson J. and Vigfússon G. (eds.) 1878: Biskupa sögur, Reykjavík.

Toury, Gideon 1995: Descriptive Translation Studies and Beyond, Amsterdam.

Tveitane M. (ed.) 1972: 'Elis saga', 'Strengleikar' and Other Texts: Uppsala University Library, Delagardieska samlingen Nos. 4-7 Folio and AM 666 b Quarto, Oslo.

Wolf K. 2001: “Gregory's Influence on Old NorseIcelandic Religious Literature", in R.H. Bremmer Jr., K. Dekker and D. F. Johnson (eds.), Rome and the North. The Early Reception of Gregory the Great in Germanic Europe, Paris-Leuven-Sterling, 255-274. 